\title{
Ownership Structure, Managerial Turnover and Takeovers: Further U.K. Evidence on the Market for Corporate Control ${ }^{*}$
}

\author{
Jay Dahya \\ University of Wales College of Cardiff, U.K. \\ Ronan Powell \\ Queen's University of Belfast, Northern Ireland
}

This article investigates the impact that successful hostile and friendly takeovers have on the rates of top management change for U.K. target firms. The results shows that hostile takeovers are associated with a greater degree of both top executive and top team forced departure rates compared to that of friendly takeovers. Furthermore, prior to takeover, hostile targets have lower abnormal returns, lower profitability, higher debt, lower managerial ownership and a high ownership stake held by external block holders relative to friendly targets. The results give further support to the disciplining role of the hostile takeover (JEL G3).

Key words: managerial control, hostile takeover, top management turnover, friendly takeover, ownership structure

\section{Introduction}

The threat of takeover, operationalized through the capital markets, is regarded by many as one of the key factors in maintaining good managerial control. Several papers, predominately U.S. in origin, have shown that takeovers, and hostile takeovers in particular, serve as a useful external control mechanism for removing managers who fail to

${ }^{*}$ The authors would also like to express their gratitude to the ACCA for funding this project. They are particularly grateful for the helpful comments and constructive criticism received from the Editor Nickolaos Travlos. The article benefited from discussions that have taken place with many academics and practitioners. Particular mention should be made to Rick Antle, Geoffrey Whittington, Richard Taffler, David Power, and Alasdair Lonie.

(Multinational Finance Journal, 1998, vol. 2, no. 1, pp. 64-86)

(C) Multinational Finance Society, a nonprofit corporation. All rights reserved. DOI: $10.17578 / 2-1-3$ 
maximize firm value, e.g., Morck, Shleifer, and Vishny (1989); Martin and McConnell (1991); and Ikenberry and Lakonishok (1993). This control is regarded by many as the single most important external factor in encouraging good managerial performance. Advocates of this view suggest that other mechanisms of managerial control, such as internal board controls, the managerial labor market and product market competition, are ineffective in encouraging the efficient management of corporations, e.g., Grossman and Hart (1980); and Rappaport (1990). When other mechanisms fail to influence managerial performance, the external market for corporate control comes into play and acts as a 'court of last resort' (Jensen, 1988, p. 319).

In the U.S. literature, there is strong support for the role of the takeover as an external check on managerial performance. Hostile takeovers, in particular, are argued to be disciplinary in nature since they tend to be directed at poorly performing firms, where performance is measured by stock market performance (Martin and McConnell, [1991]). Morck et al. (1989) find similar results on hostile takeovers using stock market performance and Tobin's $q$. Furthermore, they identify separate firm-specific and industry-specific effects. In contrast, U.K. research has failed to provide strong support for the disciplining motive of the hostile takeover. For example, Franks and Mayer (1996) find that hostile bids in the U.K. do not appear to be directed at poorly performing firms. On the other hand, Kennedy and Limmack (1996) find poor prior performance to be mainly a characteristic of target firms.

A second approach often adopted in the literature for testing whether the market for corporate control provides an external check on managerial performance is to examine board turnover following the completion of the takeover especially in poorly performing firms. If key board members (e.g., CEO, managing director and finance director) are removed after completion of the transaction, it is likely that the takeover was motivated by poor target managerial performance. Such takeovers are likely to be hostile, and hence, disciplinary in nature. Board turnover research in the U.S. (Walsh [1988]; Martin and McConnell [1991]; Walsh and Ellwood [1991]; and Agrawal and Walkling [1994]) find that successful takeovers trigger a forced restructuring of the board in poorly performing target firms. Furthermore, the rate of management turnover in successful takeovers is higher for hostile bids compared to friendly bids, giving further support to the disciplining motive for hostile takeovers. In the U.K., Kennedy and Limmack (1996) find that poorly performing targets trigger successful takeovers and a subsequent 
restructuring of the board. However, the authors make no distinction between routine and forced top management changes. Franks and Mayer (1996) find a forced restructuring of the target board following successful hostile takeovers. Moreover, unlike the previous authors, they find no evidence of significantly poor performance prior to the acquisition. A careful examination of the above articles reveals that they are not entirely comparable with those conducted in the U.S.A. Therefore, the conflicting U.K. results warrant additional research and this article sheds more light on the subject by focussing on both top executive and top team forced departure rates by exploring the differences in the rates of top management changes following successful hostile and friendly takeover bids. This article also tests whether (1) pre-bid market- and accounting-based performance measures (2) pre-bid growth in size, and (3) pre-bid changes in ownership characteristics in target companies, are able to explain more precisely the differences in the rates of top management change between successful hostile and friendly takeover bids. A comparison of ownership structures between friendly and hostile target firms is undertaken as an additional test on the role of the market for corporate control.

The remainder of the article is organised as follows. The next section of the paper reviews the relevant corporate control literature. Section III describes the sample and data employed. Section IV reports the empirical results and section $\mathrm{V}$ concludes with a summary of the main points of the paper and avenues for future research.

\section{Literature Review}

This section reviews the literature concerning two main issues. First, a brief discussion is provided on the role and effectiveness of both internal and external control mechanisms on managerial control. Second, the literature on management turnover is reviewed with particular reference to studies that have explored the link between management turnover and firm performance. The section concludes with testable propositions on the basis of this literature review.

\section{A. Board of Directors as a Mechanism of Managerial Control}

One of the primary responsibilities of the board of directors is to monitor and assess their firm's performance. The most striking actions 
which can be taken by the board of directors (sometimes with the help of majority shareholders) and even more vigorously by the boards of acquiring firms in a takeover situation, is the dismissal of the CEO and/or other members of the top management team.

To perform this function effectively, the board of directors must assume the task of extracting information about the true managerial performance of the firm from noisy and sometimes disguised or misleading financial performance measures. Both accounting and market-based measures are likely to be relatively useful indicators, though both of these measures may be determined in part by factors beyond the control of the firms managers; e.g., industry and economy effects. Furthermore, these measures are likely to be prone to the influence of managerial inputs and outputs, which themselves may provide indicative information on managerial performance (Joskow and Rose [1994]). In the U.S. and the U.K., managerial performance is maintained (and agency problems limited) by the complementary intervention of both internal and external control mechanisms (Franks and Mayer, [1996]). These mechanisms include: (1) monitoring and exerting an influence on control through the team of executive and nonexecutive directors on the board (Coughlan and Schmidt [1985]; Weisbach [1988]); (2) the managerial labor market (Fama [1980]); (3) product market competition (Hart [1984]); and (4) the market for corporate control (Jensen [1988]).

\section{B. The Failure of Internal Control Mechanisms}

The internal control mechanisms of corporations operate through the board of directors, who generally maintain the power to hire and fire top management. There is, however, considerable controversy on the role of the board of directors in this governance process. Fama (1980) and Fama and Jensen (1983) view the board as an important internal mechanism for disciplining incumbent management. Mace (1986), on the other hand, questions the importance of the board and non-executive directors as monitors.

The importance of internal control mechanisms has increased in the U.S., due partially to legal and regulatory developments which have curtailed activity in the market for corporate control (Jensen [1991]). Furthermore, in the U.K., a re-emphasis on the importance of good internal management controls followed the publication of the Cadbury Report (1992) on corporate governance. There is, however, little 
empirical evidence on the effectiveness of internal control mechanisms in generating improvements in firm performance. Denis and Denis (1996) note that, if internal control mechanisms are effective, then there should be a greater incidence of top management changes in poorly performing companies and improvements in firm performance following changes in management. Coughlan and Schmidt (1985) and Warner, Watts and Wruck (1988) document that top management change is inversely related to prior share price performance. Weisbach (1988) documents a stronger relationship between price and top management change for firms with a greater percentage of non-executive directors on the board. These finding are consistent with the board acting as an important mechanism for disciplining poorly performing managers.

When the internal processes for change in large corporations are too slow and costly to implement the required management changes, the market for corporate control quickly responds. Morck et al. (1989) finds that hostile takeovers tend to be directed at poorly performing industries. In such cases, the hostile takeover seems to provide an efficient alternative to removing unresponsive managers when the board is reluctant or unable to remove managers. Other constraints on managerial activity, such as, competition in the product or managerial labor markets may encourage managers to behave in firm value maximizing ways. However, when these mechanisms fail the market for corporate control may serve as a "court of last resort."

\section{Takeovers as a Mechanism of Managerial Control}

The theory that underlies the functioning of the market for corporate control can be traced back to Manne (1965), who was the first to articulate the workings of a market for corporate control. Manne views the takeover as a useful mechanism for encouraging mangers to pursue shareholder wealth maximization strategies. According to Manne corporate control is a valuable asset actively traded on a market. The operation of this market depends upon the link between a firm's share price and the performance of its management. Poor performance relative to some benchmark causes a firm's share price to fall below its value under efficient management, allowing a transfer of control by encouraging takeover bids from prospective new management teams.

The nature of the bid as to whether it is hostile or friendly, will depend upon the expected source of gains from the takeover. If the takeover is primarily motivated to discipline poor managers, 
shareholders will benefit because new managers will invoke shareholder wealth maximizing strategies. A second view advances the notion that gains are created through the various forms of synergy generated through the combination of target and acquirer firms. Morck et al. (1988) show that friendly takeovers are more likely to be motivated by synergy, whereas hostile takeovers are more likely to be aimed at disciplining poorly performing top management.

The effectiveness of the hostile takeover as an external disciplining mechanism has, however, been subject to some dispute. This view advocates that takeovers in general only occur to satisfy managers own self-interests, e.g., Williamson (1964) and Malatesta (1983). Under this scenario, it is not apparent whether shareholders will benefit. Proponents of this position regard takeovers as a costly and imprecise solution to managerial control problems. ${ }^{1}$

\section{Top Management Turnover Around Takeovers}

A vast literature suggests that takeovers serve to discipline poor performers in the managerial ranks. ${ }^{2}$ Table 1 summarizes the U.S. and U.K. studies which have specifically examined top management changes around takeover bids. All these studies report a substantial increase in the number of executives leaving the firm following a successful takeover bid, irrespective of the takeover type (hostile or friendly) and of the post of the executive within the target firm's management structure. To explore the latter point, the studies are classified according to the post of the executive leaving the firm.

The first group includes those studies which report only the departure rates of top executives of the target firm following a takeover bid. For the U.S. studies, Walsh (1988) reports a relatively low top executive departure rate of 37 percent for a sample of 55 takeover bids. This is not dissimilar to the departure rate of 27.3 percent reported by Denis and Serano (1996), for a sample of 77 takeover bids over a similar 24-month period following the first announcement of the takeover bid. In contrast, Martin and McConnell (1991) found a departure rate of $60.9 \%$ in the 2-year period following the first bid, for a change in either

1. Shleifer and Summers (1988) see the hostile takeover as a destructive element which should be restricted through tougher anti-trust legislation.

2. Some authors suggest that takeover defences are designed to shield incumbent managers from these forces, e.g., Jarrell, Brickley, and Netter (1989) and Sudarsanam(1995). 
of the top two officers of 253 firms which were takeover targets between 1958 to 1984. Similar results to those reported by Martin and McConnell (1991) are confirmed by Canella and Hambrick (1993), for a sample of 96 takeovers and Agrawal and Walkling (1994) for a larger sample of 800 takeover bids. Both studies report departure rates of 51 percent and 65 percent respectively in the 2-year period after the announcement of the initial takeover bid. For the U.K., Kennedy and Limmack (1996) report a CEO departure rate of 65.84 percent, for a sample of 247 firms subject to takeover.

The second group of studies in table 1 includes those which report the departure rates for all executive directors leaving the target firm following the initial takeover bid. In this group, the U.S. studies of Walsh and Ellwood (1991) report a 38.4 percent executive departure rate for a sample of 102 target firms over the 24 months following the first bid. Hambrick and Canella (1993) report a comparable 45 percent departure rate in their analysis of non-routine executive changes for 97 firms, which had been successfully acquired over the period 1980 to 1984. For the U.K., Franks and Mayer (1996) report a higher departure rate than both the U.S. studies with a 90 percent departure rate for all executives following only 35 successful takeovers during 1985 to 1986.

\section{E. Performance and Top Management Turnover Around Takeovers}

In addition to top management turnover rates following both hostile and friendly takeovers several studies have examined pre-bid target performance. From a detailed examination of these studies, four important results emerge:

1. Takeovers are generally associated with a high level of board changes following the first takeover bid. Furthermore, successful takeovers, irrespective of whether they are hostile or friendly, tend to have a higher management turnover rate than unsuccessful bids.

2. Evidence in the U.S. and the U.K. show post-takeover restructuring of assets, particularly following successful hostile bids and to coincide with the reshuffling of assets there is also evidence of post-takeover employee lay-offs.

3. The extant empirical evidence suggests that takeovers in which the top management of the target firm either departs or is dismissed is preceded by poorer industry-adjusted share price performance relative to takeovers in which the top manager does not leave the company.

4. Target management response to a bid will depend upon the amount 
of compensation they will receive whether they are founding family members or executives with large share stakes, furthermore, on the status they will be afforded in the merged company.

\section{F. Propositions for Analysis}

Based on the literature, several testable proposition are formed.

Proposition 1: Hostile takeovers lead to a greater forced top management departure rate.

Top executive and top management team forced departure rates are reported for both hostile and friendly takeovers for the three years prior to the first bid date to one year following the first bid date. Examining pre-takeover departure rates provides valuable information on the normal or average management departure rates. Furthermore, it should also provide some indication of the efficiency of internal management control mechanisms.

Proposition 2: Hostile takeovers are associated with worse pretakeover performance compared to friendly takeovers.

Pre-takeover performance is measured by cumulative abnormal returns (CAR's) and by the change in profitability (return on capital) prior to takeover for both hostile and friendly targets. Additional variables are employed to capture other relevant attributes, such as resource problems, measured as the change in gearing and liquidity, and size, measured as the change in total assets and the change in total sales. Furthermore, the financial profile of the target is not examined in isolation, but is compared to that of it's industry financial profile. Such an approach follows closely to that of Morck et al. (1989) where an industry-adjusted effect is shown to be important in explaining the mechanism of corporate control.

Proposition 3: The managers of hostile target firms are associated with a lower equity stake in the firm than held by the directors in friendly targets prior to the first bid date.

The effectiveness of the takeover market to replace poorly performing managers will depend to a great deal on the ownership structure of the 
firm. For example, if an executive director holds a substantial equity stake in the firm then the possibility of a hostile takeover may not be a viable option. Any acquisition attempt to remove poorly performing managers may therefore need to either be abandoned or come through amicable negotiations.

\section{Sample and Data}

The aforementioned propositions are assessed using a sample of 262 successful hostile and friendly takeovers covering the period 1989 to 1992. The sample includes 38 hostile takeovers and 224 friendly takeovers. The identification of the sample was based on the Acquisitions Monthly and the Stock Market Weekly Intelligence, published by the London Stock Exchange. In this article, a hostile takeover is one in which the target management rejects the initial bid. All other bids are defined as friendly.

To examine the effectiveness of board monitoring mechanisms, we specifically compare samples of top management changes that are forced with those that are mandatory retirements. However, Warner, Watts and Wruck (1988), Denis and Denis (1995) and Dahya (1997) noted that identification of forced departures can be difficult because publications by Stock Exchange news releases in the financial press often do not fully disclose the circumstances surrounding these events due to possible litigation. To limit any errors from misclassification, we cross check all announcements. The data relating to management turnover was initially gathered from Extel and the Corporate Register. Press reports in the Financial Times were also examined for details on any pre-bid management changes. Post-bid changes were not always readily available, therefore both Extel and reports in the Financial Times were used to identify any directors previously in the target company departing from the merged entity. We therefore compare forced top management changes for which the stated reason is dismissal, resignation stepped down, personal reasons or due to poor performance - to those for which the stated reason for the change is mandatory retirement. This procedure is consistent with two recent studies that examined the relation between ownership structure and top management turnover (Denis and Sarin, 1998; Dahya, Lonie and Power, 1998). Any outstanding executives whose fate had not been accounted for were cross-checked with the Personnel Department of the acquiring firm. 
Attention now turns to the financial measures employed. One market-based measure of prior share price performance as well as three sets of accounting variables are employed to capture the target firms performance, size and resource availability. Accounting-based profitability measure, return on capital employed and market-based measure, cumulative abnormal returns, are used as a proxy for firm performance. Total sales and total assets are employed as proxies for firm size and resources availability is measured using a gearing (capital) and liquidity (quick assets) ratio. All variables are measured in terms of their change, measured from two year prior to the first bid date. All variables were extracted from Datastream.

For the 38 hostile targets, 31 had the necessary data. For the 224 friendly targets, data was available for 183 firms. From this sample of 183 friendly targets, a random sub-sample of 61 firms were selected for further empirical analysis. Data for a control sample of 35 non-target firms was also collected and analyzed further.

\section{A. Measuring the Impact of Takeovers on Management Turnover}

To measure the impact of takeovers (hostile and friendly) on target management turnover, attention is drawn to unexpected departures in the following positions: (1) top executive changes (CEO or chairman); (2) top team changes (comprising, the top executive, the managing director or the finance director); and (3) a change in any of the executive directors. ${ }^{3}$

\section{Results}

\section{A. Management Turnover Around Takeovers}

The results of our analysis of top management resignations following a successful takeover bid are reported in table 2. The results reported are for the proportion of companies, which experienced resignations after hostile and friendly takeovers of top executives, top team, etc.

In general, for the sample of 92 target firms, 47 percent experienced

3. Top management changes following a successful takeover can occur in various forms. For example, the top management in the target firm can be (1) promoted to the board of the acquirer, (2) retained in the same post with the same status, (3) demoted within the targets board, and (4) fired from the targets board. 
a change in the top executive category following a successful takeover. In contrast, the rate of top executive change was only 16.5 and 17.5 percent for $y-3$ and $y-2$. Surprisingly, the rate of 26 percent in $y-1$, is 8 percent greater then that experienced in $y-3$, suggesting top executive departures increase prior to the first bid by the acquirer. This may, in retrospect, be capturing the complementary functioning of the vigilance of the board of directors and also the first stage in the operation of the market for corporate control, whereby information about the likelihood of a bid results in a greater degree of monitoring by the board. This pattern is also evident in top team and executive director departures.

When our sample of 92 targets is partitioned according to whether the initial bid was hostile or friendly, three distinct results emerge. First, both groups report top executive and top team turnover rates below 26 percent in $y-3$ and $y-2$, while in $y-1$, the sample of hostile targets report a substantially higher rate of departures in two out of the three groupings. For example, the proportion of companies which experienced top executive departures for the hostile group is 45 percent, which is 29 percent higher than the sample of friendly targets. Second, the rate of top executive departures of 54.5 percent in the 12-month post-takeover period for hostile targets is 9.5 percent greater than the proportion experienced in the previous twelve months. Furthermore, the rate nearly triples for friendly targets. Finally, all hostile targets experienced at least one executive change following the first bid, while only 76 percent of the friendly targets experienced a director resignation. The latter set of results seems to suggest that following hostile takeovers, acquiring companies seem to perform a greater degree of disciplining at all levels compared to friendly takeovers. These findings are consistent with those reported in the U.S. studies of Walsh (1988), Martin and McConnell (1991), Walsh and Ellwood (1991), Agrawal and Walkling (1994) and they are in line with the U.K. findings of Franks and Mayer (1996). Also, based on the present findings, the U.K. results of Kennedy and Limmack (1996) do not seem to be affected by the lack of distinction between forced and unforced top management changes.

\section{B. Pre-bid Financial Characteristics}

Table 3 reports the pre-bid $C A R$ 's and the growth in the median (mean) over $y-2$ to $y-1$ and $y-1$ to $y$, in size, profitability, gearing and liquidity for the sample of 92 successful takeovers and both hostile and friendly 
groups. For the total sample, both size measures (total sales and total assets) and capital gearing show abnormally large levels of growth in both $y-2$ to $y-1$ and $y-1$ to $y$, which are statistically significant at the 5 percent level using both the Wilcoxon test and the $t$-test. Target firms in general, report negative pre-takeover growth in profitability in the 12 months preceding the first bid announcement and also exhibit poor growth in their liquidity levels. These findings agree with the findings recorded by Kennedy and Limmack (1996), but contrast with those reported by Franks and Mayer (1996). A possible reason for the differences in the findings between Franks and Mayer's results with Kennedy and Limmack's and our findings could be due to the existence of internal corporate governance structures which may deter hostile takeovers from taking place even when firms are exhibiting lacklustre performance.

When the pre-takeover profitability and share price performance of the two sub-groups (hostile and friendly) in table 3 is analyzed, several interesting results concerning the dissimilarity in performance patterns emerges. Hostile takeovers report the most dramatic decline in profitability, of almost 22 percent in the 12 months prior to the announcement of the first bid, while friendly takeovers experience a lower decline of only 13 percent over the same period. Both groups also report a substantial decline in the availability of liquid funds and CAR's over the same 12-month period. This result intuitively supports the notion postulated by Morck et al. (1989) that hostile takeovers are more likely to exhibit poorer pre-takeover performance than friendly takeovers. Even when both the industry-adjusted growth in accounting profits as well as market-based returns is examined, hostile takeovers seem to report a poorer growth level than friendly takeovers in the 12 months preceding the takeover.

Both hostile and friendly takeovers also report a significant growth in their (unadjsuted) size over both pre-takeover periods. Interestingly, pre-takeover growth levels in (unadjsuted) size for both $y-2$ to $y-1$ and $y-1$ to $y$ found in the sample of hostile targets are consistently larger than for the sample of friendly targets. This provides some support for the hypothesis that acquiring firm managers select high growth targets in order to enhance their own companies growth potential.

Finally, friendly takeovers in both pre-takeover periods increased their levels of indebtedness at a statistically significant level, while hostile targets were surprisingly, found to lower their levels of debt in the period immediately preceding the takeover. When the industry- 
adjusted growth in capital gearing is examined, it is apparent that friendly targets were actually raising their debt levels at a rate which was well below the rate at which firms in the whole industry raised their indebtedness. On the other hand, hostile targets generally display a growth level in debt in excess of the industry norm in the 12 month pretakeover period.

\section{Pre-bid Ownership Characteristics}

Even though performance may be poor for target firms, hostile takeovers may not be possible when, for example, top executives are either entrenched with a substantial equity stake in the firm and or when there are no significant external block-holders maintaining a large equity stake in the firm. This section examines changes in the pre-bid levels of ownership characteristics. Table 4 presents the pre-takeover changes in the levels of directors holding and majority holdings for both friwndly and target firms.

Among both hostile and friendly targets, there is a significant difference in the directors holdings and in the proportion of shares held by the majority external shareholders. Executives in friendly targets are reported to hold 7.98 percent of the shares in their own firm, while directors of hostile targets only hold a meagre 1.92 percent. As regards the largest holding for each takeover group, 22.7 percent of the friendly targets shares were held by the majority shareholder, who in almost half of the cases was also a director of the company. On the other hand, the majority external shareholder in the sample of hostile takeovers only held around 11-13 percent of the shares of the target in the pre-takeover period. These results compare favourably to those reported by Morck et al. (1989), who also found friendly takeovers were associated with executives with large share stakes in the company.

The combination of results on internal board and external majority holdings, provide tentative evidence to suggest that friendly takeover bids are targeted at firms in which management are entrenched with a large shareholding in the target firm and they are not threatened by the existence of large external block-holders. Under such circumstances, gaining control via a hostile bid would be difficult. ${ }^{4,5,6}$

4. A disciplinary motive in friendly takeovers cannot be ruled out since one in four top executives of friendly targets depart following the first bid announcement.

5. The data and analyses for the control sample of 35 firms were not disclosed nor discussed in the main text to restrict the overall length of the paper. Three main results 


\section{Summary And Avenues for Further Research}

This paper examined the impact of successful takeover bids, hostile and friendly, on target management turnover. It extends prior work on the subject by considering the differences in the turnover rates for different positions within the top management structure and by explaining the differences in management resignations experienced by hostile and friendly takeovers in their post-bid period. In addition, this study employs both pre-bid market- and accounting-based performance measures and corporate governance characteristics to help explain the differences in post-takeover top management departure rates. Our results provide evidence that hostile takeovers are associated with a greater degree of top management disciplining at all ranks compared to friendly takeovers. Other findings suggest that (1) Hostile targets have poorer pre-takeover profitability compared to friendly takeovers (even when $C A R$ 's and industry-adjusted profitability are examined) (2) Hostile targets have rising debt levels prior to takeover, at a rate which is above the industry norm (while, friendly takeovers raise their gearing in accordance with levels below the industry norm) (3) Hostile target management tend to hold an unsubstantial proportion of equity in the firm, while directors in friendly targets tend to be highly entrenched and/or there are no significant external blockholders maintaining a large stake in the firm, and (4) Takeovers in general, appear to be targeted at high growth firms, providing some evidence for the growth related

emerge from this data. First, the average top management team turnover rate was only $9 \%$. Second, these firms recorded a steady growth in firm size, profitability and liquidity over the same period. Finally, the mean change in the ownership of the directors (over the 2 yearperiod) was only $3.25 \%$.

6. Following the suggestion of an anonymous referee, a multinomial-logit model was used to predict overall/forced/friendly turnover probabilities by the pre bid characteristics of targets as explanatory variables; the procedure is similar to the one employed in Huson, Parrino and Starks (1998). Three principle findings emerged from this analysis. First, the probability of overall management turnover was not significantly related to prior industryadjusted profitability, share price performance, and managerial equity ownership. Second, once all turnovers were dichotomised into homogenous groups according to the nature of the top management change (i.e. retirements and forced departures), a different picture emerged. The probability of forced management turnover was inversely related to prior performance, and management equity ownership at the 95 percent confidence interval. Finally, as one might have anticipated, the probability of routine retirements was not related to prior performance or managerial equity ownership. The findings of this model are qualitatively similar to those reported in tables 3 and 4 . 
explanations for takeovers.

The major implications of this study are (1) hostile takeovers in the U.K. tend to be disciplinary in nature only when executives hold a meagre equity stake in the firm and are directed at financially fragile firms who seem to be managed in a lacklustre fashion, as evidenced by poor pre-bid market- and accounting-based performance, and (2) many targets of hostile acquisitions are those firms who maintain higher than average growth prospects.

\section{References}

Agrawal, A., and Walkling, R. 1994. Executive careers and compensation surrounding takeover bids. Journal of Finance 49: 985-1014.

Bhagat, S., and Jefferis, R. 1995. Corporate performance, governance and discipline: The impact of defensive activity of takeovers and managerial turnover. Working Paper. Graduate School of Business, University of Colorado.

Coughlan, A., and Schmidt, R. 1985. Executive compensation, managerial turnover and firm performance: An empirical investigation. Journal of Accounting and Economics 7: 43-66.

Datta, D.; Pinches, G.; and Narayan, V. 1992. Factors influencing wealth creation from mergers and acquisitions: A meta analysis. Strategic Management Journal 13: 67-84.

Denis, D., and Denis, D. 1995. Performance changes following top management dismissals. Journal of Finance 50: 1029-1057.

Denis, D., and Serano, J. 1996. Active investors and management turnover following unsuccessful control contests. Journal of Financial Economics 40: 239-266.

Fama, E. 1980. Agency problems and the theory of the firm. Journal of Political Economy 88: 288-307.

Fama, E., and Jensen, M. 1983. Separation of ownership and control. Journal of Law and Economics 26: 301-325.

Franks, J., and Mayer, C. 1990. Takeovers, capital markets and corporate control: A study of France, Germany and the U.K. Economic Policy: A European Forum 10: 189-231.

Franks, J., and Mayer, C. 1996. Hostile takeovers and the correction of managerial failure. Journal of Financial Economics 40: 163-181.

Grossman, S., and Hart, O. 1980. Takeover bids, the free rider problem, and the theory of the corporation. Bell Journal of Economics 11: 42-64.

Hambrick, D., and Canella, A. 1993. Relative standing: A framework for understanding departures of acquired executives. Academy of Management Journal 36: 733-762. 
Herzel, L., and Shepro, R. 1990. Bidders and Targets: Mergers and Acquisitions in the US. Blackwell, Oxford.

Hirshleifer, D., and Thakor, A. 1991. Managerial performance, boards of directors and takeover bidding. Working paper, Anderson Graduate School of Management, UCLA.

Ikenberry, D., and Lakonishok, J. 1993. Corporate governance through the proxy contest: Evidence and implications. Journal of Business 66: 405-436.

Jarrell G.; Brickley, J.; and Netter, J. 1989. The market for corporate control: The empirical evidence from three decades. Journal of Law and Economics 23: 371-407.

Jenkinson, M., and Mayer, C. 1992. Hostile Takeovers. Macmillan: London.

Jensen, M. 1988. The takeover controversy: Analysis and evidence. In Coffee, J. Lowenstein, L. and Ackerman, R. (eds.), Knights, Raiders and Targets: The Impact of the Hostile Takeover. Oxford University Press: Oxford.

Jensen, M. 1991. Corporate control and the politics of finance. Journal of Applied Corporate Finance 4: 13-33.

Jensen, M., and Ruback, R. 1983. The market for corporate control: The scientific evidence. Journal of Financial Economics 11: 5-50.

Kennedy, V., and Limmack, R. 1996. Takeover activity, CEO turnover, and the market for corporate control. Journal of Business Finance and Accounting 23: 267-293.

Mace, M. 1986. Directors, Myth and Reality. Harvard Business School Press: Boston MA.

Mahate, A., and Sudarsanam, P. 1996. Takeover bids and their impact on analysts forecasts of target earnings. Working Paper, City University Business School, London.

Malatesta, P. 1983. The wealth effect of merger activity and the objective functions of merging firms. Journal of Financial Economics 11: 155-181.

Manne, H. 1965. Mergers and the market for corporate control. Journal of Political Economy 73: 110-120.

Martin, K., and McConnell, J. 1991. Corporate performance, corporate takeovers and management turnover. Journal of Finance 46: 671-687.

Morck, R.; Shleifer, A.; and Vishny, R. 1988. Characteristics of targets of hostile and friendly takeovers. In Auerbach, A. (ed.) Corporate Takeovers: Causes and Consequences. University of Chicago Press: Chicago: 101-129.

Morck, R.; Shleifer, A.; and Vishny, R. 1989. Alternative mechanisms for corporate control. Amercian Economic Review 79: 842-852.

Morck, R.; Shleifer, A.; and Vishny, R. 1990. Do managerial objectives drive bad acquisitions? Journal of Finance 45: 31-48.

Rappaport, A. 1990. The staying power of the public corporation. Harvard Business Review 1: 96-104.

Salter, M. and Weinhold, W. (1988), corporate takeovers: financial boom or organisational bust?. in Coffee, J., Lowenstein, L., and Rose-Ackermann, R. (eds.), Knights, Raiders and Targets. Oxford University Press: New 
York, 135-149.

Shleifer, A., and Summers, L. 1988. Breach of trust in hostile takeovers. in Auerbach, A. (ed.), Corporate Takeovers: Causes and Consequences. University of Chicago Press: Chicago.

Sudarsanam, P. 1995. The Essence of Mergers and Acquisitions: Prentice-Hall.

Walkling, R., and Long, M. 1991. Agency theory, managerial welfare, and takeover resistance. Rand Journal of Economics Spring: 54-68.

Walsh, J. 1988. Top management turnover following mergers and acquisitions. Strategic Management Journal 9: 173-183.

Walsh, J., and Ellwood, J. 1991. Mergers, acquisitions and the pruning of managerial deadwood. Strategic Management Journal 12: 201-217.

Warner, J.; Watts, R.; and Wruck, K. 1988. Stock prices and top management changes. Journal of Financial Economics 20: 461-92.

Weisbach, M. 1988. Outside directors and CEO turnover. Journal of Financial Economics 20: 431-460.

Williamson, O. 1964. The Economics of Discretionary Behaviour: Managerial Objectives in a Theory of the Firm. Englewoods Cliffs: Prentice-Hall. 
TABLE 1. Summary of the Literature on Top Management Changes Around

\begin{tabular}{|c|c|c|c|c|}
\hline Authors & Sample & $\begin{array}{l}\text { Takeovers } \\
\text { Results }^{\mathrm{a}}\end{array}$ & $(\%)$ & Comments \\
\hline Walsh (1988) & 55 USA takeover bids, $1975-79$ & $\begin{array}{l}y+1 \\
y+2\end{array}$ & $\begin{array}{l}25 \\
12\end{array}$ & $\begin{array}{l}\text { top executive was defined as either the } \\
\text { CEO or president }\end{array}$ \\
\hline $\begin{array}{l}\text { Walsh and } \\
\text { Ellwood (1991) }\end{array}$ & 102 USA targets, $1975-79$ & $\begin{array}{l}y-2 \\
y-1 \\
y+1 \\
y+2\end{array}$ & $\begin{array}{r}7.1 \\
6.8 \\
26.1 \\
12.5\end{array}$ & $\begin{array}{l}\text { definition of top team was not provided, } \\
\text { but the mean size of the top team was } \\
8.19\end{array}$ \\
\hline $\begin{array}{l}\text { Martin and } \\
\text { McConnell (1988) }\end{array}$ & 253 successful USA targets, $1958-84$ & $\begin{array}{l}y-2 \\
y-1 \\
y+1 \\
y+2\end{array}$ & $\begin{array}{r}7.1 \\
11.1 \\
41.9 \\
19.0\end{array}$ & $\begin{array}{l}\text { takeovers were defined as disciplinary if } \\
\text { a change in either of the top two officers } \\
\text { had occurred post takeover }\end{array}$ \\
\hline $\begin{array}{l}\text { Canella and } \\
\text { Hambrick (1991) }\end{array}$ & $\begin{array}{l}96 \text { USA targets listed on the NYSE, } \\
1980-84\end{array}$ & $\begin{array}{l}y+1 \\
y+2 \\
\text { senior } \\
\text { less senior }\end{array}$ & $\begin{array}{l}49 \\
49 \\
51 \\
44\end{array}$ & $\begin{array}{l}\text { this study split the sample of executive } \\
\text { changes into senior and less senior top } \\
\text { management changes }\end{array}$ \\
\hline $\begin{array}{l}\text { Agrawal and } \\
\text { Walkling (1994) }\end{array}$ & 800 USA targets, $1980-86$ & $\begin{array}{l}y-1 \\
y+1 \\
y+2\end{array}$ & $\begin{array}{r}7.7 \\
12.7 \\
35.2\end{array}$ & $\begin{array}{l}\text { results are for executive directors; } \\
\text { study also reports } 65 \% \text { of CEO's } \\
\text { depart post takeover }\end{array}$ \\
\hline
\end{tabular}


TABLE 1. (Continued)

\begin{tabular}{|c|c|c|c|c|}
\hline $\begin{array}{l}\text { Bhagat and } \\
\text { Jeffries (1993) }\end{array}$ & $\begin{array}{l}344 \text { NYSE firms that adopted takeover } \\
\text { defences, 1984-87 }\end{array}$ & $\begin{array}{l}y+1 \& y+2 \\
\text { hostile } \\
\text { friendly }\end{array}$ & $\begin{array}{l}50 \\
64\end{array}$ & $\begin{array}{l}\text { these rates are for turnover in both the } \\
\text { top two officers for firms that were } \\
\text { successful takeover targets }\end{array}$ \\
\hline $\begin{array}{l}\text { Denis and } \\
\text { Serano (1994) }\end{array}$ & $\begin{array}{l}98 \text { USA corporate control transactions } \\
\text { ( } 77 \text { takeover targets) } 1983-87\end{array}$ & $\begin{array}{l}y+1 \\
y+2 \\
y+3\end{array}$ & $\begin{array}{l}10.4 \\
14.3 \\
13.0\end{array}$ & $\begin{array}{l}\text { top manager was defined as either the } \\
\text { president or the CEO }\end{array}$ \\
\hline $\begin{array}{l}\text { Franks and } \\
\text { Mayer (1996) }\end{array}$ & 58 UK hostile bids, $1985-86$ & $\begin{array}{l}y+1 \& y+2 \\
\text { success } \\
\text { unsuccess }\end{array}$ & $\begin{array}{l}90 \\
39\end{array}$ & $\begin{array}{l}\text { rates reported are for executives turnover } \\
\text { in a sample } 58 \text { takeovers }\end{array}$ \\
\hline $\begin{array}{l}\text { Kennedy and } \\
\text { Limmack (1996) }\end{array}$ & 247 UK targets, $1980-84$ & $\begin{array}{l}y-2 \\
y-1 \\
y+1 \\
y+2\end{array}$ & $\begin{array}{l}6.5 \\
5 \\
40.1 \\
25.7\end{array}$ & $\begin{array}{l}\text { top executive of the target firm was } \\
\text { defined as the CEO but not classified } \\
\text { into forced and unforced }\end{array}$ \\
\hline
\end{tabular}

Note: Top management turnover in the corresponding years relative to the year of the successful acquisition of the target firm. For example, $y+1$ is the 12 month-period following the successful acquisition and $y-2, y-1, y+2$ and $y+3$ are defined similarly. The first seven studies in this table used US data and the last two used UK data on takeovers and top management turnover. 
TABLE 2. Top Management Changes (Forced) Around Successful Takeovers

\begin{tabular}{|c|c|c|c|c|c|c|c|c|c|c|c|c|}
\hline & \multicolumn{4}{|c|}{ All takeovers $N=92$} & \multicolumn{4}{|c|}{ Hostile takeovers $N=31$} & \multicolumn{4}{|c|}{ Friendly takeovers $N=61$} \\
\hline & $y-3$ & $y-2$ & $y-1$ & $y^{\mathrm{a}}$ & $y-3$ & $y-2$ & $y-1$ & $y$ & $y-3$ & $y-2$ & $y-1$ & $y$ \\
\hline $\begin{array}{l}\text { Executive } \\
\text { Departures }\end{array}$ & $\begin{array}{l}16.5 \% \\
(15)^{\mathrm{b}}\end{array}$ & $\begin{array}{l}17.5 \% \\
(16)\end{array}$ & $\begin{array}{r}26 \% \\
(24)\end{array}$ & $\begin{array}{r}47 \% \\
(43)\end{array}$ & $\begin{array}{r}19 \% \\
(6)\end{array}$ & $\begin{array}{r}26 \% \\
(8)\end{array}$ & $\begin{array}{r}45 \% \\
(14)\end{array}$ & $\begin{array}{l}54.5 \% \\
(17)\end{array}$ & $\begin{array}{r}15 \% \\
(9)\end{array}$ & $\begin{array}{r}13 \% \\
(8)\end{array}$ & $\begin{array}{l}16 \% \\
(10)\end{array}$ & $\begin{array}{l}42.5 \% \\
(26)\end{array}$ \\
\hline $\begin{array}{l}\text { Team } \\
\text { Departures }\end{array}$ & $\begin{array}{l}11.5 \% \\
(31)\end{array}$ & $\begin{array}{l}13 \% \\
(27)\end{array}$ & $\begin{array}{r}23 \% \\
(36)\end{array}$ & $\begin{array}{l}50.5 \% \\
(85)\end{array}$ & $\begin{array}{r}9 \% \\
(12)\end{array}$ & $\begin{array}{l}19 \% \\
(13)\end{array}$ & $\begin{array}{l}17 \% \\
(21)\end{array}$ & $\begin{array}{l}65.5 \% \\
(43)\end{array}$ & $\begin{array}{l}13 \% \\
(19)\end{array}$ & $\begin{array}{l}10.5 \% \\
(14)\end{array}$ & $\begin{array}{l}22.5 \% \\
(15)\end{array}$ & $\begin{array}{l}45.5 \% \\
(42)\end{array}$ \\
\hline $\begin{array}{l}\text { Executive } \\
\text { Departures }\end{array}$ & $\begin{array}{l}32.5 \% \\
(40)\end{array}$ & $\begin{array}{l}34.5 \% \\
(42)\end{array}$ & $\begin{array}{l}51 \% \\
(82)\end{array}$ & $\begin{array}{r}87 \% \\
(216)\end{array}$ & $\begin{array}{l}30 \% \\
(12)\end{array}$ & $\begin{array}{r}31 \% \\
(14)\end{array}$ & $\begin{array}{l}58 \% \\
(35)\end{array}$ & $\begin{array}{l}100 \% \\
(112)\end{array}$ & $\begin{array}{r}35 \% \\
(28)\end{array}$ & $\begin{array}{r}35 \% \\
(28)\end{array}$ & $\begin{array}{r}44 \% \\
(47)\end{array}$ & $\begin{array}{r}76 \% \\
(104)\end{array}$ \\
\hline
\end{tabular}

Note: ${ }^{a} Y$ is the 12-month period following the first bid date. ${ }^{\text {b}}$ Figures in parentheses indicate the actual number of director resignations experienced by firms in the respective groups. ${ }^{c}$ Top executive departures refer to the percentage change in either the chief executive officer (CEO) or chairman otherwise. To test the robustness of this definition we analyse the percentage change in the top management team which includes the posts of CEO (or chairman other wise) and managing director or finance director, in the sample firms. 
TABLE 3. Pre-bid Financial Characteristics

\begin{tabular}{|c|c|c|c|c|c|c|c|c|c|c|c|c|}
\hline & \multicolumn{4}{|c|}{ All takeovers $N=92$} & \multicolumn{4}{|c|}{ Hostile takeovers $N=31$} & \multicolumn{4}{|c|}{ Friendly takeovers $N=61$} \\
\hline & \multicolumn{2}{|c|}{ Firm } & \multicolumn{2}{|c|}{ Industry-adjusted } & \multicolumn{2}{|c|}{ Firm } & \multicolumn{2}{|c|}{ Industry-adjusted } & \multicolumn{2}{|l|}{ Firm } & \multicolumn{2}{|c|}{ Industry-adjusted } \\
\hline & $\begin{array}{l}y-2 \\
\text { to } y-1\end{array}$ & $\begin{array}{l}y-1 \\
\text { to } y_{\mathrm{a}}\end{array}$ & $\begin{array}{l}y-2 \\
\text { to } y-1\end{array}$ & $\begin{array}{l}y-1 \\
\text { to } y\end{array}$ & $\begin{array}{l}y-2 \\
\text { to } y-1\end{array}$ & $\begin{array}{l}y-1 \\
\text { to } y\end{array}$ & $\begin{array}{l}y-2 \\
\text { to } y-1\end{array}$ & $\begin{array}{l}y-1 \\
\text { to } y\end{array}$ & $\begin{array}{l}y-2 \\
\text { to } y-1\end{array}$ & $\begin{array}{l}y-1 \\
\text { to } y\end{array}$ & $\begin{array}{l}y-2 \\
\text { to } y-1\end{array}$ & $\begin{array}{l}y-1 \\
\text { to } y\end{array}$ \\
\hline \multicolumn{13}{|l|}{ A. Size } \\
\hline Total Assets & $\begin{array}{c}15.21 \\
(42.4)\end{array}$ & $\begin{array}{c}10.72 \\
(29.5)\end{array}$ & & & $\begin{array}{l}18.08 \\
(61.3)\end{array}$ & $\begin{array}{l}14.21 \\
(29.5)\end{array}$ & & & $\begin{array}{c}14.39 \\
(18.3)\end{array}$ & $\begin{array}{c}9.65 \\
(21.6)\end{array}$ & & \\
\hline $\begin{array}{l}\text { W-Test. } \\
\text { T-Test }\end{array}$ & & $\begin{array}{c}.06 \\
(.03)^{*}\end{array}$ & & & & $\begin{array}{c}.39 \\
(.21)\end{array}$ & & & & $\begin{array}{r}.01 * \\
(.02)\end{array}$ & & \\
\hline $\begin{array}{l}\text { Total } \\
\text { Sales }\end{array}$ & $\begin{array}{r}5.63 \\
(57.2)\end{array}$ & $\begin{array}{c}10.65 \\
(32.5)\end{array}$ & & & $\begin{array}{l}25.21 \\
(70)\end{array}$ & $\begin{array}{c}19.25 \\
(49.3)\end{array}$ & & & $\begin{array}{c}18.39 \\
(46.5)\end{array}$ & $\begin{array}{r}9.52 \\
(12.9)\end{array}$ & & \\
\hline $\begin{array}{l}\text { W-Test } \\
\text { T-Test }\end{array}$ & \multicolumn{2}{|c|}{$\begin{array}{l}(.00)^{* *} \\
(.00)^{* *}\end{array}$} & & & \multicolumn{2}{|c|}{$\begin{array}{l}(.00)^{* *} \\
(.05)^{* *}\end{array}$} & & & \multicolumn{2}{|c|}{$\begin{array}{l}(.00)^{* *} \\
(.01)^{*}\end{array}$} & & \\
\hline \multicolumn{13}{|l|}{ B. Profitability } \\
\hline $\begin{array}{l}\text { Return on } \\
\text { capital Employed } \\
\text { W-Test } \\
\text { T-Test }\end{array}$ & $\begin{array}{c}.14 \\
(35.7) \\
.13 \\
(.11)\end{array}$ & $\begin{array}{l}-19.3 \\
(-10.2)\end{array}$ & $\begin{array}{c}.04 \\
(.03) \\
.05^{*} \\
(.35)\end{array}$ & $\begin{array}{c}.02 \\
(.04)\end{array}$ & $\begin{array}{c}10.08 \\
(90.4) \\
.64 \\
(.59)\end{array}$ & $\begin{array}{l}-21.75 \\
(-50.5)\end{array}$ & $\begin{array}{c}-.01 \\
(-.08) \\
.01 * \\
.04 *\end{array}$ & $\begin{array}{l}.03 \\
(.06) \\
*\end{array}$ & $\begin{array}{c}-9.67 \\
(-4.01) \\
.09 \\
.07\end{array}$ & $\begin{array}{c}-12.97 \\
(13.2)\end{array}$ & $\begin{array}{c}.02 \\
(.03) \\
.42 \\
.75\end{array}$ & $\begin{array}{c}.04 \\
(.02)\end{array}$ \\
\hline C. Gearing & & & & & & & & & & & & \\
\hline
\end{tabular}


TABLE 3. (Continued)

\begin{tabular}{|c|c|c|c|c|c|c|c|c|c|c|c|c|}
\hline $\begin{array}{l}\text { Capital } \\
\text { gearing }\end{array}$ & $\begin{array}{r}5.41 \\
(35.3)\end{array}$ & $\begin{array}{r}3.69 \\
(45.4)\end{array}$ & $\begin{array}{l}-.05 \\
(-.04)\end{array}$ & $\begin{array}{l}-.02 \\
(-.06)\end{array}$ & $\begin{array}{r}5.22 \\
(-3.5)\end{array}$ & $\begin{array}{l}-4.40 \\
(22.9)\end{array}$ & $\begin{array}{l}-.03 \\
(-.06)\end{array}$ & $\begin{array}{c}.03 \\
(-.09)\end{array}$ & $\begin{array}{r}6.81 \\
(-3.5)\end{array}$ & $\begin{array}{r}5.99 \\
(52.9)\end{array}$ & $\begin{array}{c}-.01 \\
(.01)\end{array}$ & $\begin{array}{l}-.04 \\
(.04)\end{array}$ \\
\hline W-Test & & $.00 * *$ & & .44 & & .03 & & .69 & & $.02 *$ & & .60 \\
\hline T-Test & & $(.00)^{* *}$ & & $(.51)$ & & $(.04)^{*}$ & & (.68) & & $(.01)^{* *}$ & & $(.65)$ \\
\hline \multicolumn{13}{|c|}{ D. Liquidity } \\
\hline Quick & -11.51 & -23.29 & .02 & .01 & 5.39 & -48.21 & .00 & -.02 & -18.25 & -27.63 & .02 & .01 \\
\hline Assets & $(4.4)$ & $(24.4)$ & $(.03)$ & $(.02)$ & $(46.9)$ & $(70.5)$ & $(-.01)$ & $(.01)$ & $(-13.3)$ & (6.4) & (.03) & $(.04)$ \\
\hline W-Test & & $.05 *$ & & .48 & \multicolumn{2}{|c|}{$.03 *$} & .55 & & \multicolumn{2}{|c|}{$.00 * *$} & .60 & \\
\hline T-Test & & $(.08)$ & & $(.80)$ & \multicolumn{2}{|c|}{$(.07)$} & $(.47)$ & & $(.01)^{\prime}$ & & $(.57)$ & \\
\hline
\end{tabular}

E. Cumulative Abnormal Returns

\begin{tabular}{|c|c|c|c|c|c|c|}
\hline & $\begin{array}{c}\text { Days } \\
t-506 \text { to } t-6\end{array}$ & $\begin{array}{c}\text { Days } \\
t-256 \text { to 6-6 }\end{array}$ & $\begin{array}{c}\text { Days } \\
t-506 \text { to } \mathrm{t}-6\end{array}$ & $\begin{array}{l}\text { Days } \\
t-256 \text { to } \mathrm{t}-6\end{array}$ & $\begin{array}{c}\text { Days } \\
t-506 \text { to } \mathrm{t}-6\end{array}$ & $\begin{array}{c}\text { Days } \\
t-256 \text { to } t-6\end{array}$ \\
\hline $\begin{array}{l}\text { Pre-announcement Cars } \\
\text { (P-value-t-test) }\end{array}$ & $\begin{array}{l}.29 \\
(.18)\end{array}$ & $\begin{aligned}-1.83 \\
(.01)\end{aligned}$ & $\begin{array}{r}-6.32 \\
(.01)\end{array}$ & $\begin{array}{r}-7.54 \\
(.01)\end{array}$ & $\begin{array}{l}2.87 \\
(.36)\end{array}$ & $\begin{aligned}-2.01 \\
(.02)\end{aligned}$ \\
\hline
\end{tabular}

Note: ${ }^{a, b} * *$ and $*$ indicates statistical significance at the 1 and 5 per cent confidence levels (p-values) for Wilcoxon tests (T-test).

Abnormal share returns are generated using the market model procedure with parameters estimated over the 200 days beginning 11 days before the event for the announcement period and 300 days beginning 507 days before the event for the 500 day-period pre-announcement returns. 
TABLE 4. Pre-bid ownership Characteristics

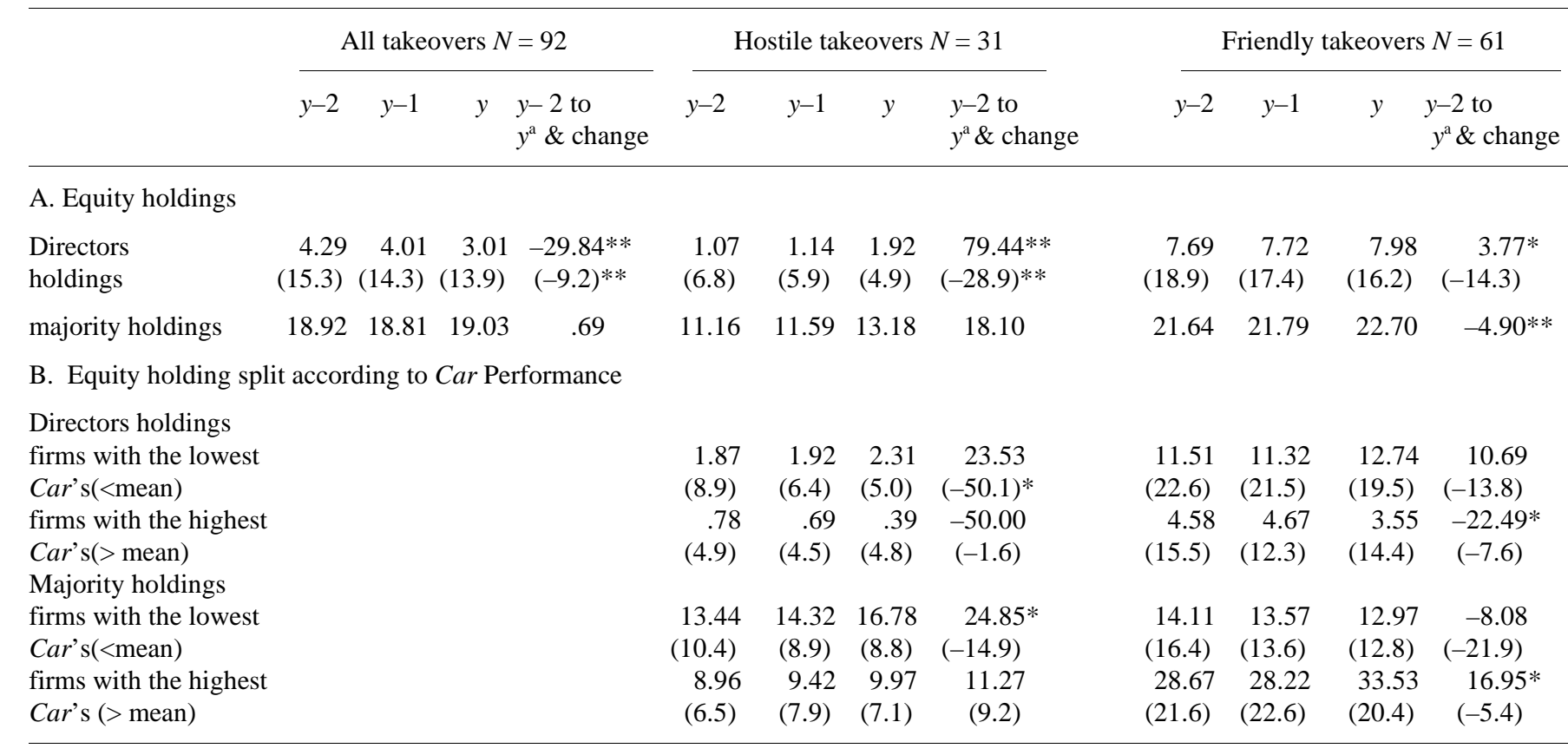

Note: **and *indicates statistical significance at the 1 and 5 percent confidence levels (p-values) for Wilcoxon tests (T-tests) between $y-2$ and $y$. 